\title{
SEROLOGICAL DETECTION OF SEED BORNE VIRUSES INCOWPEA REGENERATED GERMPLASM USING PROTEIN A SANDWICH ENZYME LINKED IMMUNORSORBENT ASSAY
}

\author{
O.B. OJUEDERIE ${ }^{1,3}$, B.O. ODU ${ }^{2,3}$ and C.O. ILORI \\ Department of Crop Protection and Environmental Biology, University of Ibadan, Ibadan, Nigeria \\ ${ }^{1}$ Department of Biotechnology, (Current address of author) College of Food Sciences, Bells University \\ of Technology, Ota, Ogun, State,Nigeria \\ ${ }^{2}$ Department of Crop Production and Protection, Faculty of Agriculture, Obafemi Awolowo University, \\ Ife, Nigeria \\ ${ }^{3}$ Genetic Resources Centre,International Institute of Tropical Agriculture, P.M. B 532O, Ibadan, Nigeria
}

(Received 2 June, 2009; accepted 2 September, 2009)

\begin{abstract}
Cowpea (Vigna unguiculata (L.) Walp) is susceptible to a number of fungal, bacterial and viral diseases. The effects of viruses can be devastating and are a major constraint to the production of cowpea. A study was carried out to detect the presence of seed borne viruses in fourteen cowpea accessions screened from 300 regenerated cowpea germplasm from the genebank collection of the International Institute of Tropical Agriculture (IITA) in Nigeria. Protein A Sandwich Enzyme linked Immunosorbent Assay (PAS ELISA) was used to detect seed borne viruses in the accessions. Out of 36 accessions of TVu 2033 indexed, 31 were infected with Cowpea aphid-borne mosaic virus genus Potyvirus, which is of great economic importance in germplasm conservation and exchange between countries as it causes great loss. Southern bean mosaic virus was not detected in any of the accessions evaluated. Seeds were harvested from the infected mother plants at maturity and the embryos excised in vitro onto hormone free medium composed of $4.43 \mathrm{~g}$ MS basal salt, $30 \mathrm{~g}$ sucrose and $8 \mathrm{~g}$ of agar. The seedlings obtained were serologically indexed to detect any seed-borne viruses after acclimatisation to screen house conditions. The seedlings obtained from excised embryos got from harvested seeds gave a negative ELISA result.
\end{abstract}

Key Words: Embryo culture, PAS ELISA, Vigna unguiculata

\section{RÉSUMÉ}

Le niébé (Vigna unguiculata (L.) Walp) est sensible à un certain nombre de maladies fongiques, bactériennes et virales. Les effets des virus peuvent être dévastateurs et constituent un obstacle majeur à la production de niébé. Une étude a été effectuée pour détecter la présence de virus transmis par la semence dans quatorze accessions de niébé sélectionnées parmi les 300 régénérées à partir du germoplasme collecté dans la banque de gènes de l'Institut International d'Agriculture Tropicale (IITA) au Nigeria. Un test PAS ELISA (Protein A Sandwich Enzyme linked Immunosorbent Assay) a été utilisé pour détecter les virus transmis par la semence dans les accessions. Parmi les 36 accessions testées de TVu 2033 indexées, 31 étaient infectées par le virus du genre Potyvirus (Cowpea aphid-borne mosaic virus ), virus réputé d'une grande importance économique dans la conservation du germoplasme et l'échange entre les pays eu égard aux pertes qu'il entraîne. "Southern bean mosaic virus” n’a pas été détecté dans aucune des accessions évaluées. Les semences ont été récoltées à la maturité à partir des plantes mères infectées et les embryons excisés in vitro sur un milieu sans hormone, composé de 4,43 g de sel MS, $30 \mathrm{~g}$ de saccharose et de $8 \mathrm{~g}$ d'agar. Les plantules obtenues ont subi un test sérologique afin de détecter tous les virus transmis par la semence après l'acclimatation dans la serre. Les plantules obtenues à partir d'embryons de graines excisées ont donné le résultat négatif d’ELISA.

Mots Clés: Culture d’embryon, PAS ELISA, Vigna unguiculata 


\section{INTRODUCTION}

Cowpea is an important leguminous crop in tropical and subtropical areas of Asia, Africa and Latin America, as well as parts of southern Europe and the USA (Singh et al., 1997; Boukar et al., 2004). It was estimated that 3.3 million tonnes of cowpea dry grains were produced world-wide in year 2000. Nigeria produced 2.1 million tonnes of this, making it the world's largest producer, followed by Niger (650,000 tonnes) and Mali (110,000 tonnes) (IITA, 2004; Adegbite and Amusa, 2008). According to FAO, about 7.56 million tonnes of cowpea are produced worldwide annually on about 12.76 million hectares. Sub-Saharan Africa accounts for about $70 \%$ of total world production (IITA, 2009). High protein and lysine contents make cowpea a natural supplement to staple diets of cereals, roots and tubers commonly grown in many poor countries (Bressani, 1985; Adekola and Oluleye, 2007).

Cowpea is a common food crop throughout Nigeria but particularly in the middle belt and drier northern regions. All of these factors make cowpea a vital crop to millions of poor people. Cowpea is susceptible to a number of fungal, bacterial, and viral diseases. The effects of viruses can be devastating and are a major constraint to the production of cowpea (Thottappilly and Rossel, 1992).

Of more than twenty viruses reported on cowpea from different areas of the world, eight are known to occur in cowpea in Africa (Mali and Thottappilly, 1986; Brunt et al., 1990). Passage of viral inoculum from diseased plants to their offspring was long thought to be a rare phenomenon. Today, seed transmission is known to occur for about one-seventh of the known viruses in one or more of their hosts (Hull, 2002), and the number is increasing. Three important effects of seed transmission are: (i) direct and/or indirect injury, as even a low incidence of infected seeds sown results in numerous randomly scattered foci of inoculum, facilitating early secondary spread in the crop vectors, (ii) survival of viral inoculum from one crop season to the next; and (iii) several viruses and viroids have been, and undoubtedly still are, disseminated worldwide through exchange of seeds having undetected infection (Albrechtsen, 2006).
Viral diseases can cause severe damage to cowpea crops. Cucumber mosaic virus (CMV) genus Cucumovirus has shown to be highly seed borne in many cowpea varieties (Thottappilly and Rossel, 1988).

Although $14 \%$ reduction in yield is attributable to CMV in the USA (Pio-Riberio et al. 1978), yield reduction in cowpea due to CMV has not been documented in Nigeria. A threeyear survey indicated that CMV was detected only in 1993 with an incidence of $4.2 \%$ and prevalence of 22.7\% (Shoyinka et al. (1997). Cowpea aphid borne mosaic virus (CABMV), genus Potyvirus, is seed borne in cowpea at a rate $0-40 \%$ (Thottappilly and Rossel, 1988), but seed transmission depends on the virus strain and cowpea cultivar (Ladipo, 1977; Aboul Ata et al., 1982). It has since been found in all ecological zones in Nigeria, where it is considered the most widespread and most important viral disease of cowpea (Thottappilly and Rossel 1992; Shoyinka et al., 1997).

Also, Cowpea yellow mosaic virus (CYMV) genus Comovirus is seed borne at low levels (rates of $0-5 \%$ ) (Thottappilly and Rossel, 1985). According to the report of a three-year survey conducted by Shoyinka et al. (1997), CYMV ranked next to CABMV in importance in Nigeria. The incidences were 27.1, 5.2 and 19.9\%; and the prevalences were $63.9,19.0$ and $40.9 \%$ for 1991 , 1992, and 1993, respectively.

Southern bean mosaic virus (SBMV) genus Sobemovirus is seed borne at rates of $3-4 \%$ (Thottappilly and Rossel, 1988). In a three-year survey conducted in Nigeria between 1991 and 1993, SBMV had the highest incidence (27.4\%) and prevalence (66.7\%). It was not detected in any of the fields in 1992, but resurfaced with a reduced incidence (7.9\%) and prevalence (27.3\%) in 1993 (Shoyinka et al. 1997).

In contrast to the situation some decades ago, highly sensitive and reliable methods for virus detection well-suited for seed testing, are now available. Among antibody-based methods, enzyme-linked immunoassay have become the principal ones, being highly sensitive, relatively simple to use and suited for large scale testing. (Albrechtsen, 2006). A recent nucleic-acid based method, the polymerase chain reaction (PCR), has higher specificity, extremely sensitive and 
automated. It is now increasingly being used in diagnostic laboratories, but it lacks simplicity and it is expensive. Most laboratories in developing countries are not yet conversant with this method.

Meristem tip culture technique has proved to be a very useful tool for eliminating viral pathogens from crop plants. Indeed, such a system will have applications in eliminating internally seed borne viruses from grain legumes (Kartha et al., 1981). This is very important as it aids the successful transfer of virus-free germplasm between countries. Conservation of virus free seeds of cowpea and other legumes in germplasm collections requires the same attention as the conservation of vegetatively propagated crops in in-vitro cultures.

The objectives of this study were to (i) identify the viruses present in infected accessions, and (ii) ascertain if the viruses detected were seed borne or seed transmissible.

\section{MATERIALS AND METHODS}

Greenhouse screening. Three hundred cowpea accessions from the IITA germplasm collection were screened for symptoms of cowpea viruses in the greenhouse. A total of 14 accessions, which showed external virus-like symptoms were selected for this study. Two hundred seeds were selected for each of the 14 cowpea accessions that showed virus-like symptoms, and planted in trays containing sterilised soil in an insect free screen house (Fig. 1). The 14 cowpea accessions used were TVu 3923, TVu 3640, TVu 2728, TVu2010, TVu2939, TVu3076, TVu3766, TVu 3830, TVu 3906, TVu 3722, TVu 3433, TVu 2033, TVu 3657 and TVu 2651.

Virus indexing. Two weeks after planting, the cowpea accessions were screened for virus-like symptoms and the numbers of seedlings showing virus-like symptoms was expressed as a percentage of germinated seedlings. The viruses present were confirmed using Protein A Sandwich Enzyme linked Immunosorbent Assay (PAS ELISA) (Hughes and Thomas, 1988).

Two test wells were given to each sample in form of duplicates while 6 wells were given for the 3 healthy control samples. Two wells were also given to the positive control. The averages

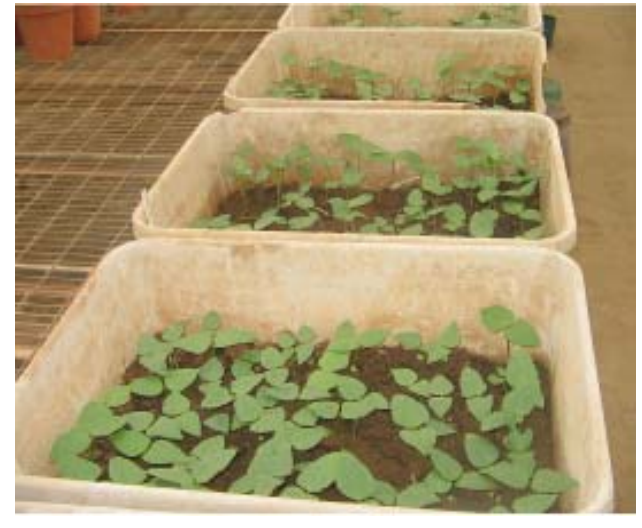

Figure 1. Cowpea accessions grown in trays containing sterilised soil in vector free screen house.

of the test- and positive- samples were used to determine whether a sample was +ve (infected) or -ve (healthy). A sample was considered infected when the mean absorbance value of the wells containing the samples was at least twice the absorbance of the wells of the healthy controls. A universal microplate reader (ELx 800) was used to read the absorbance at $405 \mathrm{~nm}$.

Embryo culture, culture media and conditions. The seeds obtained from infected mother plants were harvested and embryo culture was carried out. The harvested seeds were surface sterilised in $70 \%$ ethanol for 2 mins and then transferred into a beaker containing $10 \%$ sodium hypochlorite (commercial bleach) solution with two drops of Tween 20 for 20 minutes. The seeds were rinsed thrice with sterile distilled water.

A second sterilisation was done in $20 \%$ sodium hypochlorite solution with two drops of Tween 20 for 5 mins. The seeds were rinsed thrice with sterile distilled water, before dissection using a stereomicroscope and a light source in a laminar flow hood.

A medium without exogenous hormone was used to culture the excised embryos. This medium was composed of $4.43 \mathrm{~g}$ MS basal salt Murashige and Skoog (1962), $30 \mathrm{~g}$ sucrose and $8 \mathrm{~g}$ of agar. The culture tubes containing the media were autoclaved at $121^{\circ} \mathrm{C}$ at $1.06 \mathrm{~kg} \mathrm{~cm}^{-2}$ pressure for 15 mins. maintained at $24 \pm 2^{0} \mathrm{C}$ under a 12 -hr photoperiod provided by cool white fluorescent lamps. After rooting was observed, the plants were subcultured into liquid medium and later 
acclimatised in a containment room. The design used was a completely randomised design.

Data analysis. Analysis of variance was used to test the statistical significance using SAS/PC 9.1 version and means showing significant differences were separated using LSD at 95\% level of significance.

\section{RESULTS AND DISCUSSION}

Out of the fourteen accessions screened (Table 1), twelve had virus symptoms, while two showed no symptoms at all. The incidence of Cowpea aphid borne mosaic virus (CAbMV) was significantly $(\mathrm{P}<0.05)$ different from Cowpea mosaic virus (CMV), Southern bean mosaic virus (SBMV) and Cowpea yellow mosaic virus (CYMV) in the twelve genotypes detected with viral infection at $0.05 \%$ probability (Table 2 ). One major virus, CAbMV, was detected in most of the accessions used (Table 3). Cowpea aphid borne mosaic virus (CAbMV) is important economically for safe germplasm conservation and transfer between countries, as it causes great loss in crop yield (Fig. 2). TVu 2033 was highly infected with seed borne Cowpea aphid borne mosaic virus compared to other accessions (Table 4). TVu 2033 also had mild infection from cowpea yellow mosaic virus and cucumber mosaic virus (Table 3, Fig. 3)

Natural infections of cowpea often involve virus mixtures (Singh and Allen, 1980), which may lead to synergism or possibly cross protection, and to erroneous records if these are based only on symptomatology. Southern bean mosaic virus was not detected in the accessions studied (Table 3). The control plants did not produce visible viral symptoms throughout the growth of the plants and were negative in the PAS ELISA test.

The reaction of the various accessions to the detected seed borne viruses appears to be genotype dependent. The excised embryos of the seeds harvested from infected mother plants, tested negative after the plants were acclimatised in the screen house and indexed at the four leaf stage using PAS ELISA (Hughes and Thomas, 1988) (Fig. 5). Seed transmissibility of a virus depends upon its (virus) capacity to attack the
TABLE 1. List of cowpea accessions used in this study in Nigeria

\begin{tabular}{lll}
\hline IITA Acc number & Cultivar name & Origin \\
\hline TVu 3923 & Ex- Okuta & Nigeria \\
TVu 3640 & PI579977 & Cameroun \\
TVu 2728 & PI352876 & India \\
TVu 2010 & Lobia-1-Safade & Afghanistan \\
TVu 3076 & P1353240 & India \\
TVu 3766 & KR107 & Nigeria \\
TVu 3830 & Introgression & Nigeria \\
TVu3657 & Subs. Cylindrica & China \\
TVu 2033 & Kano 14 & Nigeria \\
TVu2651 & Matwapa & Kenya \\
TVu3433 & PI354694 & India \\
TVu3722 & Weedy & Nigeria \\
TVu3906 & CLS-11 & India \\
TVu2939 & PI353094 & India \\
\hline
\end{tabular}

TABLE 2. Incidence of seed borne viruses on cowpea accessions

\begin{tabular}{llc}
\hline Virus type & $\begin{array}{c}\text { Virus mean of Incidence } \\
\pm \text { standard error }\end{array}$ & $\begin{array}{c}\text { Number of } \\
\text { genotypes }\end{array}$ \\
\hline CAbMV & $5.00000 \mathrm{a} \pm 2.51360$ & 12 \\
CMV & $0.08333 \mathrm{~b} \pm 0.08333$ & 12 \\
CYMV & $0.08333 \mathrm{~b} \pm 0.08333$ & 12 \\
SBMV & $0.00000 \mathrm{~b}$ & 12 \\
\hline
\end{tabular}

Means followed by the same letter are not significantly different at $0.05 \%$ level of significance

floral meristem during the earliest stage of its differentiation. Seed-transmitted viruses are always carried within the embryo. Viruses may be present in the seed coat, nucellus, endosperm and other seed parts but are not transmissible if not present within the embryo (Gupta et al., 1985). If seed-transmitted viruses are carried in the embryo, it is expected that the embryos will be infected. This suggests that the viruses detected in this study were not present within the embryo of the seeds produced by the infected mother plants, and were, therefore, not seed transmissible but seed borne.

\section{CONCLUSION}

Stringent screening methods such as the reverse transcription polymerase chain reaction (RT PCR) 
TABLE 3. Protein A Sandwich Enzyme linked immunorsorbent assay (PAS-ELISA) detection of seedborne viruses in Cowpea accessions

\begin{tabular}{|c|c|c|c|c|c|c|}
\hline \multirow[t]{2}{*}{ TVu. $\mathrm{No}^{\mathrm{a}}$} & \multicolumn{6}{|c|}{ Antisera $^{b}$} \\
\hline & Origin & CAbMV & CYMV & CMV & SBMV & $\begin{array}{l}\text { Total plants } \\
\text { tested }\end{array}$ \\
\hline TVu2033 & Nigeria & 31 & 1 & 1 & & 36 \\
\hline TVu3640 & Cameroon & 11 & & & & 12 \\
\hline TVu3076 & India & 2 & & & & 4 \\
\hline TVu3657 & China & 3 & & & & 7 \\
\hline TVu2651 & Kenya & 1 & & & & 4 \\
\hline TVu3923 & Nigeria & 5 & & & & 6 \\
\hline TVu3722 & Nigeria & 1 & & & & 8 \\
\hline TVu2010 & Afghanistan & 1 & & & & 3 \\
\hline TVu2728 & India & 3 & & & & 4 \\
\hline TVu3830 & Nigeria & 1 & & & & 1 \\
\hline TVu3433 & India & 1 & & & & 5 \\
\hline TVu3766 & Nigeria & & & & & 5 \\
\hline
\end{tabular}

a International Institute of Tropical Agriculture identification numbers for Tropical Vigna unguiculata

${ }^{\mathrm{b}}$ Antisera results for accessions infected with Cowpea aphid borne mosaic virus, Cowpea yellow mosaic virus, Southern bean mosaic virus and Cucumber mosaic virus

TABLE 4. Rate of virus infection on cowpea accessions

\begin{tabular}{llc}
\hline Genotype & $\begin{array}{c}\text { Virus mean of incidence } \\
\pm \text { standard error }\end{array}$ & $\begin{array}{c}\text { Number of } \\
\text { viruses }\end{array}$ \\
\hline TVu2033 & $8.250 \mathrm{a} \pm 7.5870$ & 4 \\
TVu3640 & $2.750 \mathrm{ab} \pm 2.7500$ & 4 \\
TVu3923 & $1.250 \mathrm{~b} \pm 1.2500$ & 4 \\
TVu3657 & $0.750 \mathrm{~b} \pm 0.7500$ & 4 \\
TVu2728 & $0.750 \mathrm{~b} \pm 0.7500$ & 4 \\
TVu3076 & $0.500 \mathrm{~b} \pm 0.5000$ & 4 \\
TVu2010 & $0.250 \mathrm{~b} \pm 0.2500$ & 4 \\
TVu2651 & $0.250 \mathrm{~b} \pm 0.2500$ & 4 \\
TVu3722 & $0.250 \mathrm{~b} \pm 0.2500$ & 4 \\
TVu3433 & $0.250 \mathrm{~b} \pm 0.2500$ & 4 \\
TVu3830 & $0.250 \mathrm{~b} \pm 0.2500$ & 4 \\
TVu3766 & $0.000 \mathrm{~b}$ & 4 \\
\hline
\end{tabular}

Means followed by the same letters are not significantly different at $0.05 \%$ level of significance

should be used in screening all accessions present in the genebank on a regular basis in addition to PAS ELISA test, to ensure that only virus free seeds are stored in the genebank, since accessions which appear negative with ELISA could be positive when tested with RT PCR. From

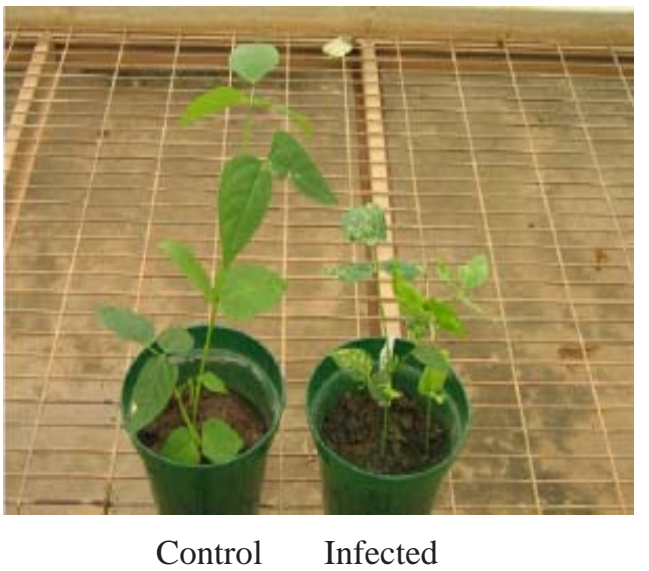

Figure 2. Cowpea accession TVu 3830 showing typical symptoms of Cowpea aphid borne mosaic virus.

all indications, cowpea aphid borne mosaic virus (CAbMV) is the most common seed borne virus of cowpea detected in seeds obtained from the ex-situ genebank in Nigeria. During harvesting, pods should only be taken from symptomless plants until serologically or otherwise tested to ensure that they are virus free. Two accessions TVu 3906 and TVu 2939 show no symptoms of virus 


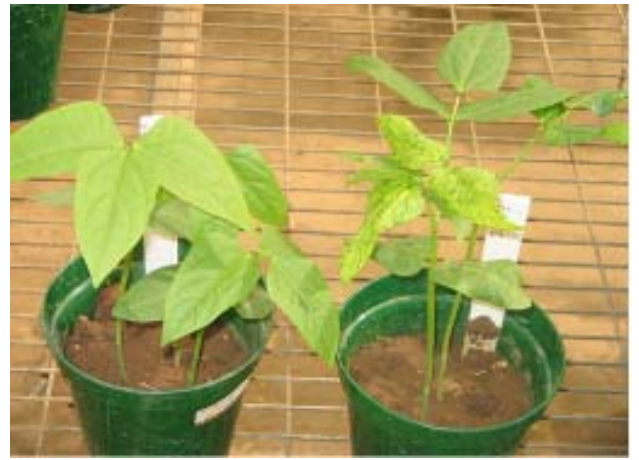

Control

Infected

Figure 3. Cowpea accession TVu 2033 showing mixed infection with Cowpea aphid borne mosaic virus (CAbMV) and Cowpea yellow mosaic virus (CYMV).

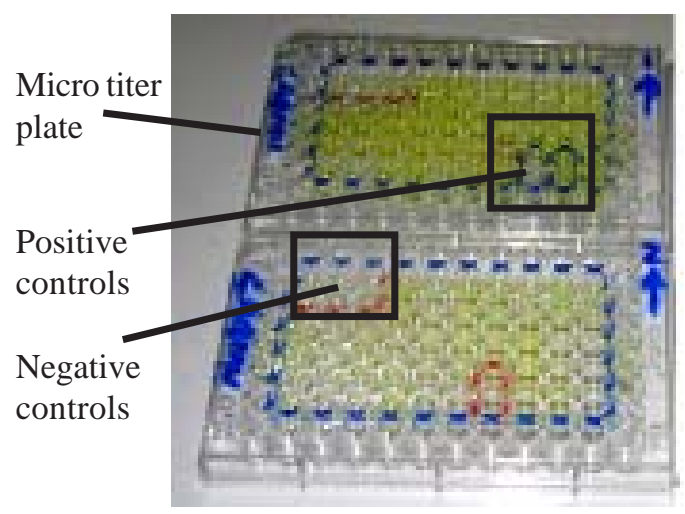

Figure 4. Protein A Sandwich enzyme linked immunosorbent assay (PAS ELISA) result for detection of CAbMV in TVu 2033.
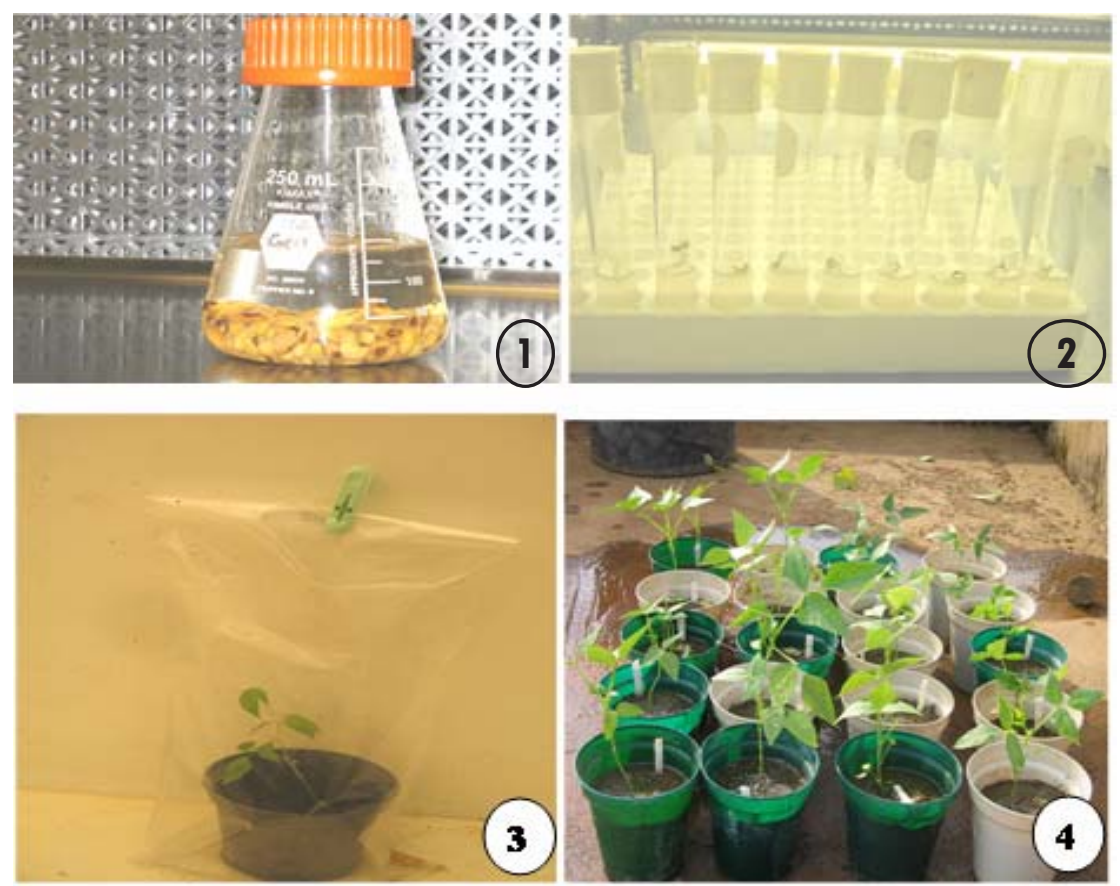

Figure 5. Embryo culture procedure and acclimatisation of 19 cowpea seedlings from infected mother plants prior to indexing (1) surface sterilisation of harvested cowpea seeds prior to embryo excision (2) excised embryos in medium without exogenous hormone (3) acclimatisation in a containment room (4) acclimatised plants in the screen house prior to indexing.

TABLE 5. Analysis of variance of effect of seed borne viruses on cowpea accessions

\begin{tabular}{lrcccc}
\hline Source & DF & Type III SS & Mean square & F Value & Pr $>F$ \\
\hline Accessions & 11 & 235.4166667 & 21.4015152 & 1.18 & 0.3400 \\
Virus & 3 & 220.0833333 & 73.3611111 & 4.03 & 0.015 \\
\hline
\end{tabular}

Virus effect is significant at $0.05 \%$ level of significance 
infection. These can be used as negative controls in ELISA tests for cowpea accessions. The viruses studied are not seed transmissible from the infected mother plants as they are not carried within the embryo.

\section{ACKNOWLEDGEMENT}

The authors are grateful to Dr. Mahalakshmi, V. for providing the facilities and materials of the Genetic Resources Centre of the International Institute of Tropical Agriculture (IITA), Ibadan, Nigeria used in this study. This study constituted part of the M.Sc. dissertation research of the first author submitted to the University of Ibadan, Nigeria.

\section{REFERENCES}

Aboul-Ata, A.E. Allen, D.J., Thottappilly, G. and Rossel, H.W. 1982. Variation in the rate of seed transmission of cowpea aphid borne mosaic virus in cowpea. Tropical Grain Legume Bulletin 25: 27

Adegbite, A.A. and Amusa, N.A. 2008. The major economic field diseases of cowpea in the humid agro-ecologies of South-Western Nigeria. African journal of Biotechnology 7:4706-4712.

Adekola, O.F. and Oluleye, F. 2007. Influence of mutation on the chemical composition of cowpea Vigna unguiculata( L.) Walp. African Journal of Biotechnology 6:4.

Albrechtsen, S.E. 2006. Testing methods for seed transmitted viruses: Principles and protocols. CABL Publishing Oxfordshire, UK 259pp.

Boukar, O., Kong, I. Singh, B.B., Murdock, L. and Olum, H.W. 2004. AFLP and AFLP- Derived SCAR MARKER Associated with Striga gesnerioides Resistance in Cowpea. Crop Science 44:1259-1264.

Bressani, R 1985. Nutritive value of cowpea. In cowpea research, production and utilization. Singh, S.R., Rachie, K.O. (Eds.), pp. 353-359. John wiley and sons, U.K.

Brunt, A. Crastree, K. and Gibbs, A. 1990. Viruses of Tropical Plants Oxon, UK: LAB Inter. Converse

Gupta, B.M. Singh,B.P., Verma ,H.N. and Srivastara, K.M. 1985. Perspectives in plant virology. Vol 1: Print House (India) Lucknow. pp. 299-314.

Hughes J.d'A. and Thomas, B.J. 1988. The use of protein A-sandwich ELISA as a means of quantifying serological relationships between members of the tobamovirus group. Annals of Applied Biology 112: 117-126.

Hull, R. 2002. Matthews Plant virology, $4^{\text {th }}$ edn, Academic Press, London, UK.

International Institute of Tropical Agriculture (IITA) 2004. IITA Crops and Farming Systems. www.iita.org/crop/cowpea.htm

International Institute of Tropical Agriculture (IITA) 2009. IITA Cereals and Legume Systems.www.iita.org/cms/details/ cowpea project details.asp

Kartha, K.K., Pahl, K., Leung, N.L. and . Mroginski, L.A. 1981. Plant regeneration from meristems of grain legumes: soybean, cowpea, peanut, chickpea, and bean. Canadian Journal of Botany 59: 1671-1679.

Ladipo L. 1977. Seed Transmission of Cowpea aphid borne mosaic virus in some cowpea cultivars. Nigerian Journal of Plant Protection 3: 3-10.

Mathur, S.B. 1995. Some aspects of seed pathology that desires immediate attention. Indian Journal of Mycology and Plant pathology 25:13-24.

Murashige T. and Skoog F. 1962. A revised medium for rapid growth and bioassay with Tobacco tissue culture. Physiologia plantarum 15: 473-497.

Pio Ribeiro,G. Wyatt,S.D. and Kuhn, C.W 1978. Cowpea Stunt: a disease caused by a synergistic

interaction of two viruses. Phytopathology 68:1260-1265

Singh, S. R. and Allen D. J. 1980. Cowpea pests and diseases. International Institute of Tropical Agriculture Manual series N0 2IITA Ibadan Nigeria.

Singh, B.B., Chambliss, O.L. and Sharma, B. 1997. Recent advances in cowpea breeding.In: B.B. Singh et al. (Ed.), pp. 30-49. Advances in cowpea research. Copublication of IITA and JIRCAS. International Institute of Tropical Agriculture, Ibadan, Nigeria.

Shoyinka, S.A., Thottappilly, G., Adebayo, G.G. and Anno-Nyako, F.O. 1997. Survey on 
cowpea virus incidence and distribution in Thottappilly, G.. and Rossel, H.W. 1988. Tropical Nigeria. International Journal of Pest. Management 43:127-132.

Mali,V.R. and Thottappilly, G. 1986. Virus diseases of Cowpea in the Tropics. In: Raychadhuri, S.P. and Verma, J.P. ( Eds.). Reviews of Grain Legume Bulletin 34:27

Thottappilly, G. and Rossel, H.W. 1992. Virus diseases of cowpea in Africa. Tropical Pest Management 38:337-348

Tropical Plant Disease 3:361-403. 